\title{
DECREEING ORGANIZATIONAL CHANGE: JUDICIAL SUPERVISION OF PUBLIC INSTITUTIONS*
}

\author{
DONALD L. HOROWITZ**
}

\begin{abstract}
In the last ffteen years or so, courts have issued a small but signifcant number of decrees requiring that governmental bodies reorganize themselves so that their behavior will comport with certain legal standards. Such decrees, addressed to school systems, prison and mental hospital officials, welfare administrators, and public housing authorities, insert trial courts in the ongoing business of public administration. In this article, Professor Horowitz traces the origins, characteristics, and consequences of organizational change decrees. He finds their roots in an unusually fuid and indeterminate system of procedural forms and legal rules, a system hospitable to the impact of changing ideas about the performance of bureaucracy and the role of courts. He explores the problematic character of organizational change litigation, underscoring the ways in which organizational behavior is fraught with a variety of informal relationships beyond the contemplation of the courts. In Professor Horowitz's judgment, efforts to augment the capacity of courts to cope more effectively with organizational change litigation may redound to the disadvantage of the judicial process by emphasizing the new managerial role of the courts at the expense of their traditional moral function. He concludes by suggesting that capricious budgetary ramifications, unintended consequences, and the impact of unconventional enforcement practices on the courts themselves be included among the elements of a full evaluation of organizational change litigation.
\end{abstract}

A century and a half ago, Alexis de Tocqueville wrote that in the United States the "language of the law" is "a vulgar tongue." By that he meant simply that American culture was so peculiarly suffused with legalism that "the whole people" was aceustoined to discoursing in legal terms. ${ }^{1}$ It is not surprising that such a people should experience

* Copyright (C 1983 by Donald L. Horowitz

* Professor of Law, Duke University School of Law.

This article is a revised version of a paper presented at the Twelfth Annual Chief Justice Earl Warren Conference on Advocacy, sponsored by the Roscoe Pound-American Trial Lawyers Foundation, in Charlottesville, Virginia, in June 1983. A solnewhat different version will appear in a voluine of conference papers to be published by the Foundation under the title SEPARATION OF POWERS. The author is indebted to the Foundation for its hospitality and support in inaking the paper and the article possible.

1. A. DE Toceueville, Democracy in AMerica 12 (1945 ed.). 
high rates of litigation, that its lawyers and judges should be conspicuous and powerful figures, that the ambit of what is characterized as a legal issue should be broad, or that the boundaries between the legal system and the political and social systems should be uncertain, shifting, and permeable. All of these are familiar, even commonplace, but still cogent observations about our culture.

Less commonplace but equally important is the observation that our governmental institutions are unusually phiable and adaptable. ${ }^{2}$ We have a separation of powers but no clearcut division of labor. We are accustomed to functional overlap and redundancy among institutions, often the product of our willingness to turn institutions to new purposes. The legalization of political discourse, coupled with the general elasticity of institutional boundaries, has created a venerable tradition in the United States of turning to the courts when battles are lost in other forums.

Yet, if the courts traditionally provided another opportunity for disappointed claimants contesting governmental action, the nature of that opportunity was circuinscribed by some characteristic modes of judicial operation. The claim had to be presented in the context-or at least the clothing - of a lawsuit; the outcome, even if at variance with the outcome in the legislature or the bureaucracy, was ordinarily cast in terms of a decision merely permitting or forbidding certain conduct. There was plenty of room for creativity, no doubt: statutes might be reconstructed beyond the dreams of their draftsinen; constitutional provisions might be enlarged to dimensions previously unknown. ${ }^{3}$ But, until the 1960's, the courts had rarely, if ever, told states and federal government agencies something other than that they legally could or could not do what they had been doing. The courts had not, in short, prescribed for thein what they inust do. ${ }^{4}$

Since the 1960's, however, federal and, to a lesser extent, state courts have issued a relatively small but highly significant number of "structural mjunctions." 5 The defendants have been such governmental bodies as school systems, prison officials, welfare administrations, mental hospital officials, and public housing authorities. ${ }^{6}$ Structural injunctions, or institutional reform decrees, are orders requiring that gov-

2. See S. Huntington, American Politics: The Promise of Disharmony 127 (1981).

3. See, e.g., Adkins v. Children's Hosp., 261 U.S. 525 (1923); Lochner v. New York, 198 U.S. 45 (1905).

4. Mandamus directed to administrators was reserved for purely ministerial acts.

5. The term belongs to Owen Fiss, InJunctions 415-82 (1972).

6. For a good recent survey, see S. Fluckiger, J. Heller, \& D. Krause, The Changing Role of the Judiciary in Public Management and Governance (unpublished paper prepared for the National Academy of Public Administration, March 1983). 
ernmental bodies reorganize themselves so that their future behavior will comport with standards announced in the underlying judicial decisions. These decrees have a number of novel characteristics.

First, they are extensive as well as affirmative in their commands. Their requirements run not to one or two acts but to a whole course of conduct, typically to both general policy and details. ${ }^{7}$ The decrees require actions whose performance cannot be accoinplished and measured rapidly, actions that may span years.

Second, the decrees are administrative in character. In varying measures, they essentially supersede the authority of the defendant body to manage its own busimess, subject to executive and legislative accountability. In some cases, such decrees entail the formal displacement of the officers of the agency and the substitution of a rcceiver or some other court-appointed officer to act in their stead. ${ }^{8}$ But, whether they involve displacement of officials or not, structural injunctions set up a new source of authority and accountability for the managers of public institutions. That new source is the courts.

Third, structural decrees are legislative in the double sense of entailing fundamental alterations of policy direction and of frequently requiring augmentation of financial resources. The basis of the underlying judicial decision is typically a wide-ranging policy determination anchored in broad statutory or constitutional provisions and having only a loose connection to the clains and interests of specific parties. ${ }^{9}$ The decree that purports to reform a public institution often injects the courts into the public budgeting process. This can occur indirectly, as it did when, following Wyatt v. Stickney, ${ }^{10}$ Alabama's spending on mental imstitutions rose from $\$ 14$ million in 1971 to $\$ 58$ million in 1973, one year after the dccree was rendered. ${ }^{11}$ Judicial budgeting can also occur directly, as it did when a federal court ordered the city of Boston to fund a bail appeal project that had lost other sources of funding, in

7. See, e.g., Hills v. Gautreaux, 425 U.S. 284, $292-93$ (1976); Hobson v. Hansen, 327 F. Supp. 844, 861-64 (D.D.C. 1971); Wyatt v. Stickney, 325 F. Supp. 781, 785-86 (M.D. Ala. 1971), supplemented, 334 F. Supp. 1341 (1971), 344 F. Supp. 373 (1972), 344 F. Supp. 387 (1972), affd in part sub nom. Wyatt v. Aderholt, 503 F.2d 1305 (5th Cir. 1974).

8. See, e.g., Hart v. Community School Bd., 383 F. Supp. 699, 758-68 (E.D.N.Y. 1974) (special master), supplemented, 383 F. Supp. 769 (1974), affd, 512 F.2d 37 (2d Cir. 1975); NAACP v. Brennan, 360 F. Supp. 1006, 1019 (D.D.C. 1973)("special master and/or hearing examiner"); Perez v. Boston Hous. Auth., 379 Mass. 703, 735-38, 400 N.E.2d 1231, 1247-49 (1980) (receiver).

9. See generally Chayes, The Role of the Judge in Public Law Litigation, 89 HARv. L. Rev. 1281 (1976).

10. 325 F. Supp. 781 (M.D. Ala. 1971), supplemented, 334 F. Supp. 1341 (1971), 344 F. Supp. 373 (1972), 344 F. Supp. 387 (1972), affd in part sub nom. Wyatt v. Aderholt, 503 F.2d 1305 (5th Cir. 1974).

11. Wall St. J., Dec. 18,1973 , at 42 , col. 1. 
order to facilitate the release of inmates incarcerated in an overcrowded jail. ${ }^{12}$ The assuinption of many institutional reform decrees has been that the courts could draw upon additional resources. Broad remedies could be implemented because it was assumed there would be compliance with what were, in substance, judicially-ordered budgetary priorities. Only in the wake of austerity in governmental budgets has it been sensed that an "absence of resources places the court in the position of having to design decrees directed solely and narrowly to the issue before the court."13

Fourth, because the decrees call for alteration of an ongoing course of conduct, for a new regime of organizational behavior, they necessitate continuing judicial involveinent in the implementation and modification of the decree. The court becomes a participant in the affairs of the defendant-organization, its clients, and its whole environment, often more than a court might wish. Monitoring of compliance with the decree becomes essential, liaison witl sucl1 adjunct personnel as masters and receivers is coinmon, periodic reporting to the court is generally required, and amendinent of the provisions of the decree from tinne to tine may be deened desirable.

Fifth, despite their innovative character, these decrees have proved remarkably resistant to appellate review. They do, of course, depend leavily on facts typically found after extensive hearmgs, and they entail the exercise of large doses of judicial discretion. On both counts, they call into play canons of appellate abstemiousness about secondguessing trial courts. The result is that major clianges in the law and in the relations among governmental bodies have been wrought mainly by trial courts. There is something of an analogy to the situation of the 1930's, when enforcement of mucl New Deal legislation was brought to a halt by imjunctions issued by solitary, hostile district judges. And there is the paradox that the remedial phase of the litigation, which is recognized as crucially inportant, receives the least attention, in terms of both procedural safeguards and appellate review.

If I have focused mainly on the characteristics of the decrees, that is not because of any conviction that the underlying declaration of rights is unimportant in such cases. On the contrary, I have spelled out elsewhere the many ways (quite apart from the decree) in which such social policy or institutional reforin cases differ from the conventional run of litigation. ${ }^{14}$ Rather, I want to underscore leere the difference in

12. Inmates of Suffolk County Jail v. Eisenstadt, 518 F.2d 1241 (1st Cir. 1975).

13. Weinstein, The Effect of Austerity on Institutional Litigation, 6 LAw \& HUM. BeHAv, 145, 147 (1982).

14. See generally D. Horowitz, The Courts and Social Policy (1977). 
remedy, because the role of the courts in the supervision of public institutions is very largely the product of recent remedial innovation. The decree that prescribes organizational change is only about fifteen years old. The suddenness of the innovation calls for a searching evaluation of the forces that brought on the innovation, what judicial supervision of public institutions entails, and the consequences such supervision may have, including consequences for the courts theinselves.

\section{The Origins of a New Judicial Role}

It makes sense to think about two kinds of change in the courts that have paved the way for judicial supervision of public organizations. One is institutional. Legal structures, rules, and doctrines inust have been available to be turned to new uses, and they must indeed have been transformed if the identification of this as a new area of judicial activity is accurate. The other change is ideological. There have been important developinents in what judges and lawyers believe, and these developments affect the outcoine of structural refonn litigation. The two kinds of change interact. The structure of legal constraints and modes of proceeding have evolved in a way that is congenial to the new conceptions, but the new conceptions could not have been put into effect without the preexisting structure of rules and traditions. An implication of this analysis is that no single development produced organizational change decrees, and no alteration of a rule or institution could, by itself, effect a reversal of course.

Although I shall treat these two kinds of change separately, the adaptability of American legal institutions has largely meant that, when beliefs changed, legal inventiveness was more than adequate to turn available institutions in a new direction. In a more hidebound, formahstic system, it is quite possible that the requisite changes would not have taken place. ${ }^{15}$ Ours is sinnly an unusually fluid and indeterminate system of procedural forms and legal rules, hospitable to accommodating an array of purposes.

\section{A. The Institutional History of Judicial Intervention.}

This exposition is intentionally sketchy and inpressionistic in two senses. First, the enumeration of institutional changes makes no pretense to completeness. An exhaustive history of such changes in a change-prone system like ours would be an exhausting (although rewarding) task, but I have not embarked on it. Second, I intend to touclı

15. Indeed, to put the point concretely, English lawyers continue to be surprised by the extent to which the American legal system is susceptible to change. 
on changes at varymg levels, subsuming them under the deliberately amorphous rubric of "imstitutional change." Consequently, I shall highlight broad traditions, specific judicial decisions, specific rules of procedure, general statutory trends, and specific practices in the conduct of litigation. This eclecticism is warranted by the contribution made by a variety of legal institutions to the contemporary judicial role in supervising public organizations. If this survey proves kaleidoscopic on that account, it may well do fuller justice to the subject than one that is more carefully focused and symmetrical.

1. The American Equity Tradition. I turn first to something so important and obvious in our legal history, so much a part of the imtellectual equipment of American lawyers, that it is in danger of being overlooked: the equity tradition. The contours of the equity jurisdiction that emerged im England, as Gary McDowell lias chroncled it in a recent volume, ${ }^{16}$ were the subject of great dispute. The controversy between Sir Edward Coke and Sir Francis Bacon is, of course, well known. Among other things, the dispute involved (1) the extent to which equity jurisdiction and law jurisdiction were to be fused or separate, (2) the extent to whicls equity was to "follow the law" or to provide an independent and even competing set of principles of redress, and (3) the extent to which equity was to be bounded by precedent. This controversy was carried over into the United States, where it was jomed witl the notion of a higher, natural law, a notion ultimately rejected in England. ${ }^{17}$ As in England, there was a recurrent fear of unbridled judicial power, and the equity power was one component of this apprehension. In spite of this fear, equity ultimately found a prominent place in American jurisprudence, especially in the aid of those constitutional rights that had a natural law foundation.

The three contentious issues of Enghish equity took a long time to resolve in the Uinited States. Witls the Field Code of 1848 in New York and its successors in other states, and with the 1938 Federal Rules of Civil Procedure, law and equity were merged, first in many state court systems and then in the federal courts. Equity, at first an exceptional remedy, came to be regarded, not as following the law, but as redressing its deficiencies. Although equity judges were, in principle, to be bound by prior cases, the spirit of the Enghish Chancellor, able to devise a new remedy ample enough to vindicate an identifiable riglit, came to pervade the American version. In short, the equity tradition

16. G. MCDOWELl, EQuity AND THE Constitution (1982).

17. See E. Corwin, The "Higher Law" Background of American Constitutional LAW (1955). 
proved unusually congenial to remedial adaptation. Particularly when constitutional rights seemed to call out for enforcement through the medium of a wide-ranging injunction, equity was available, replete with appropriate n1axims about remedies as broad as required to undo the violation.

The use of the sweeping injunction reached its apogee in the 1930's, when federal district judges enjoined the enforcement of New Deal legislation, bringing on the requirenent of three-judge district courts for such cases in 1937.18 The equitable tradition survived those events, and what we have inherited is an equity that is expansive, open and available for new problems, and not closely chained to law and legal remedies. In institutional reform cases, the operational meaning of the American equity tradition is to legitimize detailed affirmative decrees having a long life, in the name of insuring that equity does not suffer a wrong without a remedy.

2. The Managerial Premise of the Federal Rules. The adoption of the Federal Rules of Civil Procedure in 1938 did niore than merely merge law and equity. The Rules vindicated a particular version of judicial administration that sharply nodified the preexisting adversary control over all aspects of litigation. Consistent with the views of reformers such as Dean Charles E. Clark and Judges John J. Parker and Arthur T. Vanderbilt, who were intent on establishing "judge-centered control of the hitigation process," 19 the Federal Rules established on a secure footing the power of the judge as the nnanager of the case. The most notable exaniples of this activist view of judicial participation were the pre-trial conference and the pre-trial order introduced by Rule 16, but it is also implicit in the need for judges to unipire discovery disputes. ${ }^{20}$ The trial judge, in Parker's view, influential on this issue, was to "crack down on [lawyers] and make then get down to busmess." 21 Intolerant of procedural "fol-de-rol" that impeded the sharp and efficient quest for justice, Parker and his pioneer colleagues in the reform of judicial administration argued that judges should assume an active and autonomous role in shaping the contours of litigation and moving it along expeditiously, sweeping aside obstacles to

18. See 28 U.S.C. $\$ 2282$ (1970), repealed by Act of Aug. 12, 1976, Pub. L. No. $94-381, \S 2,90$ Stat. 1119.

19. The phrase belongs to my colleague, Peter G. Fish, Guarding the Judicial Ramparts: John J. Parker and the Administration of Federal Justice, 3 JusT. SYs. J. 105, 108 (1977). I am indebted to Professor Fish for his suggestions regarding the indirect impact of the Rules on institutional reform hitigation.

20. See Resnick, Managerial Judges, 96 Harv. L. REv. 374, $378-79$ (1982).

21. Fish, supra note 19, at 108. 
substantive justice. Not surprisingly, the same John Parker who sought to sweep aside procedural obstacles to substantive justice was a protagonist of an expansive view of the equity powers of the federal courts-a view that makes clearer the connection between the earlier conception of the inanagerial role of the judge and the later conception of that role.

It is, to be sure, not a short step from manager of the case to manager of the defendant-organization. Nevertheless, when other pieces fell into place, the activist posture fostered by the Federal Rules and by their proponents was hospitable to judges' stepping in, taking bulls by horns, and demanding that parties ineet the standards they lay down. The Rules were oriented toward getting results. To this end, the Rules provided a number of procedural devices to be utilized flexibly by judges willing to reach into the procedural tool kit for an instrument appropriate to a task, however difficult or unconventional it might appear.

3. Adaptable Devices: The Case of Rule 53. For our purposes, the most significant procedural device is the master made available by Rule 53. Now it is very plain to anyone who reads Rule 53 that it contemplates the appointunent of a master principally for fact-finding purposes in exceptional cases. In this respect, the rule merely codifies and makes unore precise an antecedent common law practice in the Umited States. Even then, however, the practice was neither uniformly nor enthusiastically adopted. Eighteen years before the Rules, the Supreme Court had upheld the appointment by then-District Judge Augustus N. Hand of an "auditor" to simplify and clarify issues and inake tentative findings of fact im a somewhat comphcated contract case. ${ }^{22}$ An opimion by Justice Brandeis for a divided Court established that, consistent with the constitutional right to a jury trial, and subject to legislation, trial courts have "inherent power to provide theunselves with appropriate instruments required for the perfornance of their duties." 23 The examples cited in the opimion unade it abundantly clear that all the duties referred to involved pre-trial fact-finding and simplification of the issues. Against that background, Rule 53 was framed.

Rule 53 was drawn carefully to limit the occasions justifying the appointment of a master. The rule contemplates that inasters are to function in proceedings prior to judginent, an assumption that is in evidence $\mathrm{m}$ all the subsections, those that deal with the compensation and powers of the master, the court's order of reference, the proceedings to be conducted, and the report to be rendered. Even then, Rule 53(b)

22. In re Peterson, 253 U.S. 300 (1920).

23. Id at 312 . 
provides that "reference to a master shall be the exception and not the rule," to be ordered in a jury case "only when the issues are complicated" and in a non-jury case (except where accounting is involved) "only upon a showing that some exceptional condition requires it."

For several decades, federal appellate courts exercised great care in limiting both the occasions for the employment of masters and the functions they could perform. When a district judge, faced with a congested docket, referred two protracted antitrust cases to a master to take evidence and render a report to the court, the Supreme Court rebuked him. ${ }^{24}$ Affirming an order of mandanus against the judge, the Court held that complexity, anticipated trial time, and congestion were not enough to justify the reference. Conceivably, the opinion hinted, ${ }^{25}$ a master might be utilized in the accounting required to assess damages if liability were established, but only if it would intrude unduly on the judge's time for him to do the job.

The cautious view of the Supreme Court, colored by its reluctance to permit the delegation of judicial duties, was very much in line with the accepted understandimg of Rule 53 before the 1970's. Courts saw threats to core values in what would otherwise have been insignificant decisions to refer private law cases to masters. Sitting en banc, the Third Circuit liad, for example, inandainused then-District Judge Harry Kalodner, who, in a stockholder's suit, had appointed a master to investigate the defendant-corporation, which he suspected of issuing a misleading financial statement. ${ }^{26}$ Masters, explained the court of appeals, "are only for the purpose of assisting the court to get at the facts and arrive at a correct result in a complicated piece of hitigation pending before the court. The master operates as an arm of the court. Surely lie has no wider scope of authority than the court itself." 27 The willingness of the court to issue mandamus was informed by its apprehension that inasters are susceptible to employınent in the nonjudicial function of investigation. This was a function the court was eager to discourage, for the opmion goes so far as to lay down that an order of reference may be no broader than the allegations and proofs of the parties. ${ }^{28}$ In short, the master is an adjunct of the adversary systein and nothing more.

24. La Buy v. Howes Leather Co., 352 U.S. 249 (1957).

25. Id. at 259.

26. Webster Eisenlohr, Inc. v. Kalodner, 145 F.2d 316 (3d Cir. 1944) (3-2), cert. denied, 325 U.S. 867 (1945).

27. 145 F.2d at 319 .

28. Id. at $319-20$. 
This, as I say, was the prevailing view for several decades. In 1966, the Eighth Circuit, in a decision with quite the same flavor as the earlier decision of the Third, proceeded to clieck a district judge who was about to use a master in a nonadversary way. ${ }^{29}$ After a determmation of liability in a treble-damage antitrust case, the court had asked a master to decide how mucl profit the plaintiff had lost. The order of reference, however, provided that the master could go beyond the evidence already adduced on lost profit and directed the defendants to produce an array of financial material for examination by the master, an accountant. Making clear its distaste for inquisitorial proceedimgs, even after liability lias been determined, the court of appeals held such an order of reference, authorizing "prospecting for furtler evidential possibilities," a "speculative" exploration outside the bounds of Rule $53 .{ }^{30}$

No signiflcant delegation of judicial duties, no routme use of masters, no transformation of procedure from adversary to inquisitorial or from passive to active, and no use of masters after judgment: these were the ground rules for Rule 53 until fairly recently. And then something snapped-or, inore accurately, it began to fray until it snapped.

At first, inasters were appointed to formulate school desegregation plans when plans submitted by the parties were unacceptable to the court. ${ }^{31}$ This occurred, essentially, after liability had been determined but before a remedy had been settled upon. By the mid-1970's, however, another step was taken. Masters were appointed to oversee the miplementation of decrees already rendered..$^{32}$ As we shall see, district judges and cominentators have often endorsed the utility of the master for this purpose in sweeping terms, but reviewing courts have not always been equally enthusiastic.

A few examples will clarify the nature of their reservations. Chicago Housing Authority v. Austin ${ }^{33}$ involved an inquiry by a district court into a long delay in the miplementation of its order that the supply of dwelling units be increased in the city of Chicago. The trial court

29. Arthur Murray, inc. v. Oliver, 364 F.2d 28 (8th Cir. 1966).

30. Id. at 34.

31. See Hart v. Community School Bd., 383 F. Supp. 699, 764 (E.D.N.Y. 1974), supplemented, 383 F. Supp. 769 (1974), affd, 512 F.2d 37 (2d Cir. 1975); Swann v. Charlotte-Mecklenburg Bd. of Educ., 306 F. Supp. 1291, 1312 (W.D.N.C. 1969), 311 F. Supp. 265 (1970), vacated on other grounds, 431 F.2d 138 (4th Cir. 1970), on remand, 318 F. Supp. 786 (W.D.N.C. 1970), affd, 402 U.S. 1 (1971).

32. See generally Kirp \& Babcock, Judge and Company: Court-Appointed Masters, School Desegregation, and Institutional Reform, 32 ALA. L. REv. 313 (1981); Nathan, The Use of Masters in Institutional Reform Litigation, 10 U. ToL. L. REv. 419 (1979).

33. 511 F.2d 82 (7th Cir. 1975). 
appointed a master to determine the cause of the delay and to examine all possibilities in the quest for expeditious implementation. Citing the Supreme Court's cautious construction of Rule 53, defendants sought mandamus against the trial judge. The gist of their argument was that reference of this matter to a master constituted abdication of the judicial function in favor of a delegate. Holding that the master's findings would not bind the judge, the Court of Appeals for the Seventh Circuit declined to issue the writ. A dissenting judge, however, suggested that the master's findings might provide the basis for a contempt order, which was what the trial judge seemed to have in mind. But the dissent did not attack the judge's order to the master to engage im an exploration of possibilities, a function more central to judicial supervision of public imstitutions than is fact-finding for a possible conteinpt citation.

The Chicago Housing Authority case provides something of a bridge to the later cases, in which masters have been used for much more than fact-finding or even enumerating and evaluating implementation possibilities. In a Texas prison case, for example, the Fifth $\mathrm{Cir}-$ cuit in 1982 approved the appointment of a master and six monitors after the decree. ${ }^{34}$ The court of appeals was nevertheless troubled by that portion of the order of reference that permitted the niaster to submit reports to the district court based on his own on-site observations rather than on findings generated by a hearing. This the court found to be a violation of due process. ${ }^{35}$ But, by now, so well established was the power to appoint masters after the decree was entered that the court consigned its approval on that point to footnote $234 .{ }^{36}$ There is, however, no glimmer of recognition in the opimion that the appointment of masters at the implementation stage is likely, in the nature of the enterprise, to involve precisely the sort of ex parte reports of which the court disapproved.

By the 1980's, then, the use of masters at the implementation stage is accepted, but there remains some apprehension about delegation of judicial functions and abandonment of adversary modes of proceeding. And so, even as the Court of Appeals for the Sixth Circuit affirmed the appointment of a master to formulate a school desegregation planindeed, none of the parties even challenged the appointment-it disapproved the delegation to the master of responsibility for evaluating "the constitutional sufficiency" of alternative plans. ${ }^{37}$ That, held the court,

34. Ruiz v. Estelle, 679 F.2d 1115 (5th Cir.), modified on reh'g, 688 F.2d 266 (5th Cir. 1982), cert. denied, 103 S. Ct. 1438 (1983).

35. 679 F.2d at 1163 .

36. Id. at $1160 \mathrm{n} .234$.

37. Reed v. Cleveland Bd. of Educ., 607 F.2d 737, 741 (6th Cir. 1979). 
is a legal matter, and the judge is not entitled to "out-of-court advice on legal issues." 38 Here was a confluence of delegation and nonadversariness that provoked a reaction on appeal.

The recent Rule 53 cases indicate that many of the concerns that gave rise to judicial caution in approving employment of masters survive, even though that caution has been abandoned. Underlying these developments is a growing recognition that institutional reform litigation has requirements different from those of earlier, more conventional, if protracted, litigation, requirements that justify extraordimary procedural flexibility. ${ }^{39}$ What I shall suggest later is that this much procedural flexibility may not really be compatible with the enduring sources of the earlier caution. For now, it is enough to note that the interpretation of Rule 53 changed, and changed rapidly, as new needs began to be felt. The shift in Rule 53 doctrine is powerful testimony to the pliability of our legal institutions.

4. Fee Shifting. If plaintiffs in institutional reform cases were obliged to pay their own legal fees, there would, of course, be many fewer such cases. Institutional reforn litigation largely followed the establishment of public interest law firms in the 1960's. These were funded by a variety of grantors: foundations, charitable and educational organizations, private contributors, and government. Causality was not unidirectional, however. The public interest bar argued for changes in doctrine, but the creation of that bar was itself the product of some of those changes. A liberal view of standing and class actions, for example, made litigation efforts plausible that would not have been regarded as worthwhile earlier. Public interest firms grew as doctrine shifted. When prison management and inental hospital management were no longer held to be outside the purview of judicial review, prison law and mental health law units were established to conduct further litigation. So the relationship between litigation organizations and emerging doctrine was reciprocal. Nevertheless, public interest law firms and the institutional reform litigation they conducted were both subject to the vicissitudes of charitable funding.

In the 1970's, this dependence on declining sources of external funding underwent some change. The hitigation itself began to generate funding. In Alyeska Pipeline Service Co. $v$. Wilderness Society, ${ }^{40}$ decided in 1975, the Supreme Court held that, absent statutory authori-

38. Id at 748 .

39. But see Pennhurst State School v. Halderman, 451 U.S. 1, 54 (1981)(White, J., dissenting).

40. 421 U.S. 240 (1975). 
zation, the federal courts are not permitted to award attorneys' fees to the winning party. Alyeska was bound to generate attempts in Congress to write fee provisions into legislation. The attempts met with a large measure of success. Not only has there been a proliferation of statutes allowing awards of attorneys' fees, to be paid by defendants to plaintiffs, ${ }^{41}$ but some have been construed to permit awards even if the plaintiff's counsel had agreed to serve without fee. ${ }^{42}$ In the few years before Alyeska, Congress had increasingly taken to writing fee provisions into legislation, and a flood of such provisions followed the decision. In the two years following Alyeska, thirty-seven new provisions were enacted by Congress authorizing the award of attorneys' fees. That is about as many as had been enacted in the entire pre-1960 period and not later repealed. From 1978 through 1980, Congress added yet another forty-four fee-shifting provisions. The imcrease is so dramatic that it is best depicted graphically, as in Figure 1.

Figure 1 shows that Alyeska was not alone in the generation of feeshifting provisions, but it certainly catalyzed the movement. There are now about 180 federal provisions authorizing fee awards. In the states, the practice is highly variable, but there is a trend toward imcreased shifting of fees in the direction of plaintiffs. One state shifts fees across the board, others in particular classes of cases, and some only in cases brought under particular statutes of limited applicability. ${ }^{43}$ There have, then, been piecemeal but powerful assaults on the American rule that generally requires each party to bear its own legal fees.

To be sure, the vast majority of the new statutes operate in fields with no bearing on judicial supervision of administration. But some of the new provisions are central to this matter. The Civil Rights Attorney's Fees Awards Act of $1976^{44}$ is the most important. A response to Alyeska, it allows a fee award to the prevailing party in a wide variety of enforcement actions. Substantial fees have already been awarded

41. Until Ruckelshaus v. Sierra Club, 103 S. Ct. 3274 (1983), an argument could be made for a fee award to even a losing plaintiff under several environmental statutes authorizing a fee award whenever "appropriate." See Note, Awards of Attomeys' Fees to Unsuccessful Environmental Litigants, 96 HARv. L. REV. 677 (1983). The Court in Ruckelshaus rejected this argument, however. $103 \mathrm{~S}$. Ct. at 3281.

42. See, e.g., Brandenburger v. Thompson, 494 F.2d 885 (9th Cir. 1974).

43. See Rowe, Attorney Fee Arrangements and Dispute Resolution, Law \& ConTEMP. Probs., Winter 1984 (forthcoming); Zeinans, Legal Structures and the Implementation of Public Policy: The Case of the American Rule, LAw \& ConTEMP. Probs., Wimter 1984 (forthcoming). I ain indebted to Professor Rowe for helpful cominents on fee shifting and on other inatters dealt with in Part I of this article.

44. 42 U.S.C. $§ 1988$ (Supp. V 1981). 


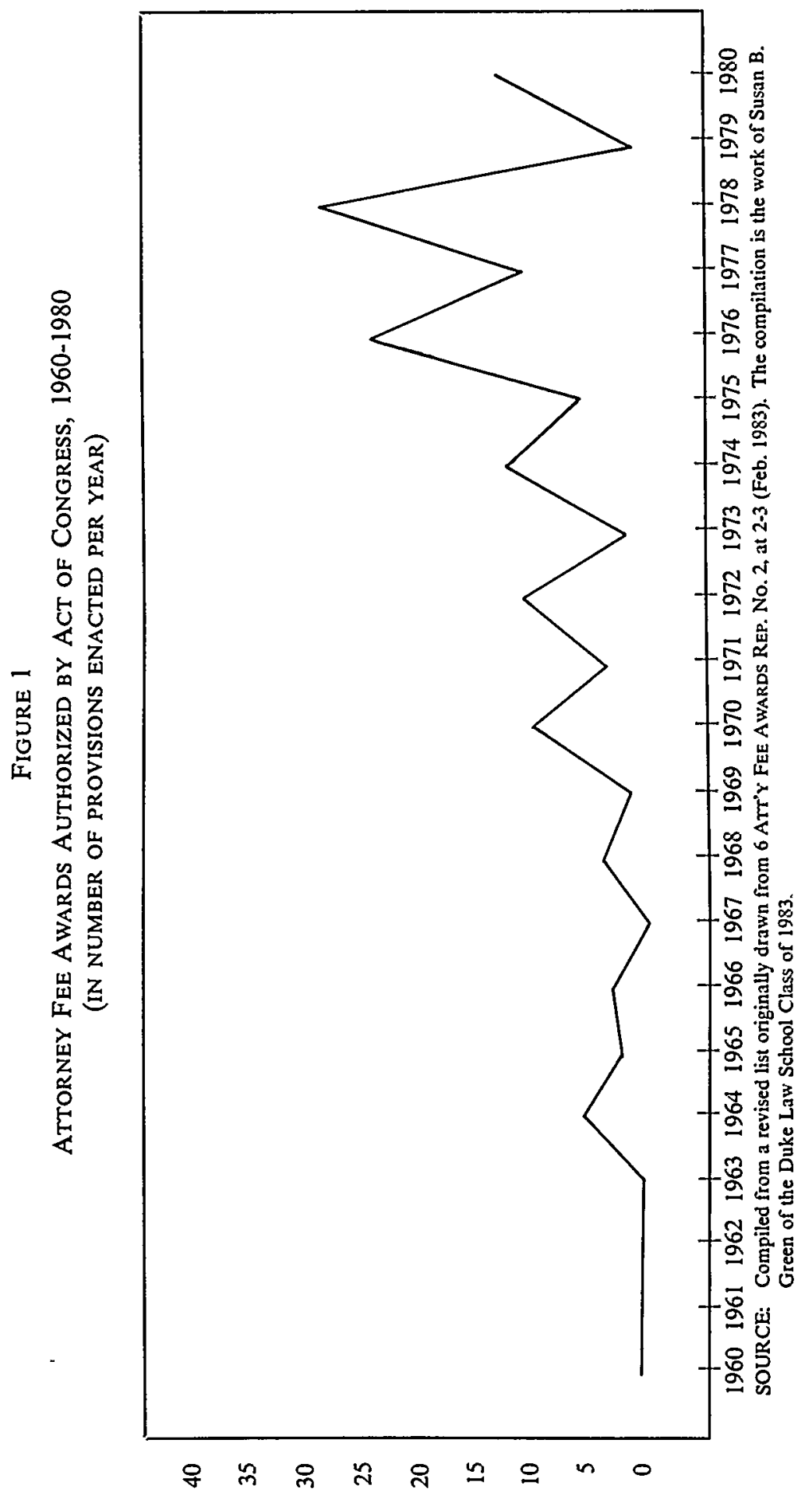


under these provisions. In the Texas prison case, discussed above, ${ }^{45}$ the district court made a fee award of \$1,662,683.46 In the Willowbrook case in New York, involving the administration of a center for retarded children and adults, a fee of $\$ 613,992$ was awarded to plaintiffs' counsel. ${ }^{47}$ And in the ongoing Chicago housing case, an interim award of $\$ 375,375$ has been affirmed by the Court of Appeals for the Seventh Circuit.48 Where one of the defendants is a state agency, attempts by state legislatures to avoid payment of fees-by refusing to appropriate funds, for example-have been rebuffed. ${ }^{49}$

In the 1970's and 1980's, fee shiftimg has provided and will continue to provide an important prop for institutional reform litigation. The dependence of public interest law firms and legal services agencies on private contributions, foundation grants, and public funding rendered institutional reform litigation vulnerable to the vagaries of philanthropic and political impulses. As those funding sources wane, feeshifting statutes may have the opposite effect of perpetuating this category of litigation. The existence of statutory authorization for fee awards in some areas but not others constitutes an incentive to bring suit in these areas, because a few generous awards can subsidize suits not generating fees. That this expectation is not fanciful is suggested by two general features of institutional reform litigation. The first is the absence or at best muted presence of live plaintiffs making litigation decisions in sucli cases. For the inost part, this is lawyer-initiated and lawyer-controlled litigation. ${ }^{50}$ The second is that some courts liave allowed the recovery of a market value fee, rather than a fee geared to the actual income of relatively low-paid public interest lawyers. ${ }^{51}$ This creates the possibility of a surplus available for use as overhead or subsidy.

5. Doctrinal Change. Much has been made of the general loosening of doctrines of standing, ripeness, mootness, political questions, and justiciability in the last two decades and of the impact this develop-

\footnotetext{
45. See supra text accompanying notes $34-36$.

46. Ruiz v. Estelle, 553 F. Supp. 567, 597-98 (S.D. Tex. 1982).

47. New York State Ass'n for Retarded Children v. Carey, 711 F.2d 1136, 1154 (2d Cir. 1983).

48. Gautreaux v. Chicago Hous. Auth., 690 F.2d 601, 614 (7th Cir. 1982), cert. denied, 103 S. Ct. 2438 (1983).

49. See Spain v. Mountanos, 690 F.2d 742 (9th Cir. 1982); Gary W. v. Louisiana, 622 F.2d 804 (5th Cir. 1980), cert. denied, 450 U.S. 994 (1981); Gates v. Collier, 616 F.2d 1268 (5th Cir. 1980). See generally Hutto v. Finney, 437 U.S. 678 (1978). (1976).

50. Cf. Chayes, The Role of the Judge in Public Law Litigation, 89 HARv. L. Rev. 1281, 1291

51. E.g., Copeland v. Marshall, 641 F.2d 880 (D.C. Cir. 1980).
} 
1nent has had on social policy and institutional reform litigation..$^{52}$ Like inany of the other developinents I have discussed, most of these doctrinal changes are both effect and cause of the new litigation. I do not intend to rehearse thein here. Two Supreme Court dccisions were, however, more the cause than the effect of judicial willingness to take on administrative responsibilities witl respect to public agencies. One of them, of course, is Brown v. Board of Education, ${ }^{53}$ which, despite the imitial diffidence of the Court, ultimately thrust federal courts into an affirmative role in the manageinent of school systeins. ${ }^{54}$ The other was Baker $v$. Carr, ${ }^{55}$ the first of the modern reapportionment cases.

Had it not been for Baker v. Carr, school desegregation inight have been regarded as a very special case. Even in Plessy v. Ferguson, ${ }^{56}$ the Supreine Court had acknowledged that segregation presented a legal question. In the case of reapportionment, that was the thing in issue, for the Court had previously held that such suits did not raise justiciable questions. ${ }^{57}$ Once Baker declared them to be justiciable, the earth quaked beneath the panoply of doctrines that had kept the courts away from the imternal affairs of other governmental bodies, legislative and administrative. After Baker refornulated the political question doctrine, it was a short step to the refornulation of comparable threshold doctrines. With the barriers lowered, the courts moved toward making judicial business nore nearly coterminous with the business of government, both state and federal. Even nore important, with the clearing of the "political thicket" 8 that took place in legislative reapportionment, state administrative terrain began to look like mere underbrush. If courts could refashion state and federal legislatures-not to inention electoral rules under the Voting Rights Act ${ }^{59}$ and patronage systeins under the first ainendinent ${ }^{60}$ - why, then, could they not refashion schools, prisons, welfare administrations, inental hospitals, housing authorities, and all the rest? What was unthinkable before be-

52. See, e.g., D. Horowitz, The Courts and Social Policy 10 (1977). For a recent doctrinal survey, see Chayes, The Supreme Court, 1981 Term-Foreword: Public Law Litigation and the Burger Court, 96 HARv. L. REv. 4 (1982).

53. 347 U.S. 483 (1954).

54. Cf. Brown v. Board of Educ., 349 U.S. 294 (1955).

55. 369 U.S. 186 (1962).

56. 163 U.S. 537 (1896).

57. See Colegrove v. Green, 328 U.S. 549 (1946).

58. Id. at 556 (Frankfurter, J., plurality opinion announcing judgment of Court).

59. See, e.g., Graves v. Barnes, 343 F. Supp. 704 (W.D. Tex.), affd sub nom. Archer v. Sinith, 409 U.S. 808 (1972), modified sub nom. White v. Regester, 412 U.S. 755 (1973).

60. See Branti v. Finkel, 445 U.S. 507 (1980); Elrod v. Burns, 427 U.S. 347 (1976); McFeeley, The Supreme Court and Patronage: Implications for Local Government, 71 NAT'L CIvic REV. 257 (1982). 
came litigable. Within a few years, the courts began to move into these areas, and by 1981-to cite one suggestive figure-litigation over prison conditions was pending in three quarters of the states. ${ }^{61}$ In accounting for the broad decree that ains to restructure public institutions, Baker v. Carr deserves equal billing witl Brown v. Board of Education.

These developments, which occurred in the sliort span of perhaps a decade and a half, had the effect of spreading judge-inade law out, noving it from the byways onto the highways. The lawsuit became more and more interchangeable with options in otler forums. And while this was happening, courts were also facilitating resort to them for redress in otlier ways. Calendars are still congested, but many courts have been especially accommodating to litigants seeking injunctions. Expedited hearing is available on inotions for injunctive relief, and often expedited appeals are available as well.62 So even the constraint of the queue has been mitigated by procedural hospitability to the injunction. Brown created a magnetic field around the courts; Baker made intrusion plausible that had earlier been summarily rejected; and court rules reduced at least some of the characteristic disincentives to litigation.

6. The Interplay of Institutions. The courts have not been responsible simgleliandedly for all of the change attributed to them. It is a mistaken view of the American system that sees each brancli as a separate actor, awaiting its proper turn. What each does affects the agenda of the others. In the case of institutional reform and social policy hitigation, the action and maction of Congress and the bureaucracy have been important accelerators of judicial intervention.

To take inaction first, it is not surprising that demands for change in the area of segregation should liave been made upon the federal government. It hardly needs saying that state governments practicing segregation were closed to those demands, and so the claims had to be pressed at the national level. But it was not foreordained that they

61. Figures vary somewhat, depending on the source consulted. From 1978 to 1983 , virtually every source lists between 30 and 42 states with prisons or prison systems in litigation or under court order. See American Civil Liberties Umion Foundation National Prison Project, Status Report-The Courts and Prisons (Jan. 28, 1983); Contact, Inc., Corrections Compendium, March 1982, at 7; National Institute of Justice, Conditions and Costs of Confinement 3, 33, 36-37 (1980) (volume 3 of the American Prisons and JaILs series); U.S. DePT. of Justice, Bureau of Justice Statistics, 1981 Sourcebook of Criminal Justice Statistics 150 (1982).

62. See, e.g., FeD. R. App. P. 8; Fed. R. CIv. P. 65; D.C. CIR. R. 6(i), 7(c)(3); 5TH CIR. R. 27(2)(11), 34(5); 9TH CIR. R. 3(g); D.D.C. R. 1(12); S.D.N.Y. R. FOR Div. OF BUS. 9. 
should be made in the judicial branch. The claims were made in court in part because of a procedural rule of the United States Senate. The rule that allows unlimited debate foreclosed legislation that might have rendered Brown superfluous. ${ }^{63}$ The civil rights filibuster was a parent of the desegregation cases.

It has long been suggested that the willingness of courts to assume broad responsibilities that entail judicial intervention into the affairs of public bodies has discouraged legislators from taking the heat. Probably there is some truth in the suggestion. But the record is a mixed one. Had the courts not broken the ice on segregation, the civil rights legislation of the 1960's would have been more problematical. There is no straight cause and effect operating here, so much as there is interaction and circularity.

On a couple of points of legislative action, however, we may feel fairly confident of a causal impact on the courts, rather than the other way around. Over the past two or three decades, Congress has been proliferating rights. No doubt, this is partly because the courts have aroused a new spirit of rights consciousness. However that may be, it is undemable that the constellation of statutory entitlements is much more dense than it was before. Many of the new rights are of the sort that impinge on the management of public institutions. ${ }^{64}$ There has, moreover, been a clearly discernible trend toward glib gcnerality in the declaration of these rights. For this tendency, there are many reasons in the legislative process. The clash of interest groups, the greater ease of sensing the existence of problems than of framing solutions, the wish to retain flexibility, the desire to please as wide a constituency as possible, the benefits of calculated ambiguity, or the serendipity of unintended ambiguity -all of these have produced a growing number of statutes embodying vague standards or none at all.65 If their meaning or their reach is unclear, someone will have to interpret them. In the first imstance, that someone will often be the administrative agency charged with implementing the law. Sometimes the agency has taken a bold view of its authority, which has then been ratified by the courts, and sometimes the agency has been found to be too timid in fulfilling

63. S.R. XIX.

64. A well-known example of the new rights is the "right to appropriate treatment" for the mentally retarded, a right declared in the Developmentally Disabled Assistance and Bill of Rights Act of 1975, 42 U.S.C. $\$ \S 6001-6081$ (1976 \& Supp. V 1981). See Pennhurst State School v. Halderman, 451 U.S. 1 (1981). Another example is the nondiscrimination provision of the Rehabilitation Act of 1973, as amended, 29 U.S.C. \& 794 (Supp. V 1981). See New York State Ass'n for Retarded Children v. Carey, 612 F.2d 644 (2d Cir. 1979).

65. For a splendid example, see Schuck, The Graying of Civil Rights Law: The Age Discrimination Act of 1975, 89 YALE L.J. 27 (1979). 
its mandate. Whether the relationship between agency and court is friendly or hostile, the court has the last word. ${ }^{66}$

In this way, what legislators and administrators have not done, what they have done, and what they have only half done have all provided the raw material for judicial action. It is by no means only the Constitution that has moved the courts into public management.

\section{B. The Intellectual History of Judicial Intervention.}

The shaping of a set of procedural rules congenial to an activist, managerial posture on the part of judges, the rapid shifts in doctrine in the course of the 1960's and 1970's, the dramatically new use of masters emerging in the 1970's, the spate of fee-shifting statutes enacted in the same decade, the legislative declaration of new rights: all testify to the importance of changing ideas behind changing institutions. The new ideas relate to the appropriate role of the courts in meeting social probleins, but they also entail a general view of the character of those problems. Barely articulated, the new ideas have nonetheless propelled institutional reform litigation forward in a powerful way.

Writing in 1980 of "The Activist Judicial Mind," Ralph Winter attributed much judicial intervention to three "reformist attitudes": (1) "hostility to a pluralist, party dominated, political process"; (2) a belief in the need for "rationality' in public policy"; and (3) "skepticism about the morality of capitalism." 67 I am less sure than Winter about the last point, but I feel quite confident about the first two (though I shall reformulate them somewhat) and about their relation to each other.

During the 1960's, a change came over much of the federal judiciary. The restlessness of that important decade affected judges, as it affected ehtes throughout the society. What it did, on the whole, was to broaden the sense of their mission and to infuse their work with a skepticism that had been notably absent before. The broadening and the skepticism were both of a special sort. Judges began to articulate their function in terins of correctimg mistakes made elsewhere. Judge J. Skelly Wright wrote a book review suggesting that the judicial role in administrative agency litigation should be conceived as a "fight to limit discretion" on the part of government bodies, in the name of "rational and permissible rule[s] of decision." 68 Although sucl1 views were not

66. See the fine article by Jeremy Rabkin, The Judiciary in the Administrative State, 71 PuB. INTEREST 62 (1983).

67. R. Winter, The Activist Judicial Mind 5 (unpublished paper presented at the American Enterprise Institute, Washington, D.C., Dec. 10, 1980).

68. Wright, Beyond Discretionary Justice (Book Review), 81 YALE L.J. 575, 581, 594 (1972). 
uniformly held on the federal bench, they were also not idiosyncratic to Judge Wright. They were quickly reflected in judicial doctrines of, for example, "strict judicial scrutiny of administrative action," 69 doctrines explicitly predicated on the fact that "the character of administrative hitigation is changing."70 The opinion of the District of Columbia Circuit in Calvert Cliffs Coordinating Committee v. United States Atomic Energy Commission ${ }^{71}$ opens with a splendid oration on the new role:

These cases are only the beginning of what promises to become a flood of new litigation-litigation seeking judicial assistance in protecting our natural environment. Several recently enacted statutes attest to the commitment of the Government to control, at long last, the destructive engine of material "progress." But it remains to be seen whether the promise of this legislation will become a reality. Therein hes the judicial role. In these cases, we inust for the first time interpret the broadest and perhaps inost important of the recent statutes: the National Environmental Policy Act of 1969 (NEPA). We must assess claims that one of the agencies cliarged witli its administration has failed to live up to the congressional mandate. Our duty, in short, is to see that important legislative purposes, lieralded in the halls of Congress, are not lost or misdirected in the vast hallways of the federal bureaucracy. ${ }^{72}$

Judge Wright was the author of this ringing prose, but he wrote for a unanimous court.

Missing from this statement of the "judicial role" is any need to decide a case, and indeed the broader conception relegates this part of the judicial function to the background. But this is not all that is noteworthy about the statement. It is suffused with distrust of bureaucracy. Whereas, for a quarter of a century, the judicial review provisions of the Administrative Procedure Act ${ }^{73}$ had largely shielded the merits of administrative agency determinations from review, by the early 1970's there was a discernible trend toward inore active, probing scrutiny of the decisions of government bodies. ${ }^{74}$ The exception to judicial review for "matters cominitted to agency discretion"75 began to be construed narrowly. ${ }^{76}$ The vaunted virtues of the administrative state, built up in the 1930's and 1940's, when great confidence was reposed in governinent, became vices during the 1960's and 1970's. "Discretion" was

69. Environmental Defense Fund v. Ruckelshaus, 439 F.2d 584, 598 (D.C. Cir. 1971).

70. Id. at 597.

71. 449 F.2d 1109 (D.C. Cir. 1971).

72. Id. at 1111 (footnotes omitted).

73. Administrative Procedure Act $\S 10(e), 5$ U.S.C. $\$ 706$ (1982).

74. See, e.g., Citizens to Preserve Overton Park v. Volpe, 401 U.S. 402 (1971); Conservation Council v. Froehlke, 473 F.2d 664 (4th Cir. 1973).

75. Administrative Procedure Act § 10, 5 U.S.C. \& 701(a)(2) (1982).

76. See, e.g., Adams v. Richardson, 480 F.2d 1159 (D.C. Cir. 1973) (en banc). 
often equated with arbitrariness. "Expertise" was tantamount to narrowmindedness. "Flexibility" seemed to connote political compronise. Judges had little taste for compromise, especially compromise with "special interests," sensing it to be at odds with principle, which they much preferred. Experts were in growing disrepute during this period. And, as Ralplı Winter says, rationality, certainly not discretion, was a reigning principle. Now judges, rather than administrators, became the expediters $\mathrm{m}$ the solution of major policy problems. ${ }^{77}$

This did not all happen at once. The courts were mucli affected by the odd mix of mehorism and distrust that characterized the 1960's: things are wrong but not so wrong that they cannot be fixed by equal doses of reason and dismterestedness; with both of these, courts are presumed to be well endowed. To some extent, the courts also appear to have been affected by what has been labeled the "post-materialism" of the post-war period. Post-materialism is characterized by an imcreasing concern with quahty-of-life, rather than economic, issues, an increasing skepticism of established political institutions (mcluding democratic ones), and growing participation in "elite-challenging, issue-oriented" groups and movements. ${ }^{78}$ This phenomenon is associated with high-mcone, high-education populations; it is very much a function of the elite culture of which federal judges might be presumed to partake.

At the same time, it is important to note that the federal judiciary is far more interconnected and probably more homogeneous than it once was. This nationalization of the bench is, in some respects, the product of the movennent toward efficient judicial administration, including establishunent of the Federal Judicial Center and attendance at semmars and conferences that put judges in contact with each other. It is also the result of the accelerated nationalization of elite legal education im the post-war period. In addition, there is far more federal law demanding some uniformity of enforcement on the part of lower federal judges. Where federal district courts were once as insular or nearly as insular as their districts, today they are plainly part of a national cadre, doing national work and responding to currents of thouglit across districts, circuits, and regions of the country.

77. See Horowitz, The Courts as Guardians of the Public Interest, 37 PUB. AD. Rev. 148 (1977).

78. R. Inglehart, The Silent Revolution: Changing Values and Political Styles Among Western PUblics 3-18 (1977); see also Inglehart, Values, Objective Needs, and Subjective Satisfaction Among Western Publics, 9 CoMp. PoL. STUD, 429 (1977). In the second half of the $1960^{\circ}$ 's, trust in government, as measured by survey data, plummeted. Miller, Political Issues and Trust in Government, 1964-1970, 68 AM. POL. SCI. REv. 951 (1974). 
The result of all of these forces is a fairly coherent view of institutional reform litigation that has emerged in the work of judges over the years. It is a view that is radically different from the conventional view of judicial work. I am not suggestmg that this view is entertamed by every federal judge - and I shall derive it from the works of just a few. Just as institutional reform hitigation comprises a small but highly significant minority of cases on the federal docket, so judges who have engaged in attempts to supervise organizational change comprise only an important minority of all federal judges. Nevertheless, it is worthwhile to attempt to articulate the components of the view that has already gamed considerable acceptance im the space of just a few years.

The emerging view embraces a theory of (1) the causes of institutional reform hitigation, (2) judicial responsibility in the context of that litigation, (3) the special difficulties presented by the litigation, and (4) the appropriate way to meet these difficulties. I shall describe each in order.

1. The sources of institutional reform cases reside in the failures of other branches of government. Government officials "succuunb to pohtical pressures to shirk their constitutional responsibilities."79 If government agencies acted in "good faith" and without "imtransigence," they would remedy their own problems. ${ }^{80}$ When they do not do their duty, the courts have "no alternative but to take a nore active role in formulating appropriate relief." 81 If the courts were to fail to meet their responsibilities in these fields, that would be to sanction an intolerable situation, namely, "rights without remedies."82 It is inconceivable that such a disparity be entertained as a possibility.

2. Underlying this appraisal is an expansive conception of judicial responsibility. The conception takes two fairly recent and significant jumps. The first is that it must fall to the courts to make good the defaults of other decisionmakers: an abdication im one branch impels a correlative performance in another, and this even across federal-state lines. Here is a new, affirmative conception of checks and balances. The other jump is the only half-spoken notion of unlimited remedies: whatever it takes, a wrong will be righted by a court. Since this new conception, inhospitable to any remedial shortfall, goes hand in hand

79. Johnson, The Role of the Federal Courts in Institutional Litigation, 32 ALA. L. REv. 271, 273, 279 (1981); see also Coffin, The Frontier of Remedies: A Call for Exploration, 67 CALIF. L. REV. 983, 985 (1979).

80. Coffin, supra note 79 , at $993,994$.

81. Johnson, supra note 79, at 274.

82. Id.; see Coffin, supra note 79, at 994. 
with the declaration of new rights-rights to treatment, to humane conditions, to mamstreaming, to rehabilitation, to quality education, etc.the remedial commitment of the courts becomes openended.

Not surprisingly, this view of the matter is not accompanied by a statement of the inescapable necessity of deciding a case properly before the court, for by now it is recognized that a sharp controversy over a precise grievance is not really what produces the litigation. Rather, the judicial function is recast more broadly. One formulation, whatever its prescriptive utility, aptly describes much of what has transpired: the courts sit "to give meaning to constitutional values in the operation of large-scale organizations." 83 The courts are, then, squarely in the business of reforming bureaucracies.

3. Having so conceived the judicial function, the courts and the cominentators are afficted with a certam ambivalence. On the one hand, they are imclined to dismiss challenges to the new role by assimilating it to customary judicial tasks: trust administration, bankruptcy admmistration, railroad reorganization. ${ }^{84}$ Only myopia, in this view, could lead to the assertion that there is anything new under the judicial sun. On the other hand, the extraordinary remedies imvoked frequently lead to an acknowledgment of novelty:

[P]ublic law litigation often places a trial judge in a position where his role is necessarily somewhat different from that performed in more traditional cases. This is especially true in the remedial phase of a school desegregation or institutional reform case. School and institutional financing and administration are subjects with which few judges have more than a passing familiarity. Yet, when litigation exposes constitutional violations in public institutions a court of equity must take steps to eliminate them. 85

The reason for the acknowledgment is clear. Unconventional remedial devices are utilized, and unconventional behavior is exhibited by judges and their delegates in such cases. The propriety of both will have to be adjudicated. Typically, the deeision is permissive, and it turns on the fact that "[ $t]$ his was not a standard lawsuit. It was a massive, long-continuing hitigation which has approximated the type involving institutional reform." 86

4. In a few short years, it has become quite cominon to point to features of such cases that require innovative remedial techniques. Institutional reform litigation may be different, and it may be difficult,

83. Fiss, The Supreme Court, 1978 Term-Foreword: The Forms of Justice, 93 HARv. L. REv. 1,5 (1979).

84. Johnson, supra note 79, at 274; see Eisenberg \& Yeazell, The Ordinary and the Extraordinary in Institutional Reform Litigation, 93 HARV. L. REv. 465 (1980).

85. Reed v. Cleveland Bd. of Educ., 607 F.2d 737, 743 (6th Cir. 1979).

86. Perez v. Boston Hous. Auth., 379 Mass. 703, 741, 400 N.E.2d 1231, 1253 (1980). 
but it is not impossible. The differences can be accommodated. Resources are available: "proven experts" 87 can help solve problems. Masters and receivers can be utilized. ${ }^{88}$ No doubt the remedial stage is the hardest-and especially because of the intransigence of the organizational defendants in complymg with the niandate of the court-but the judiciary is sufficiently adaptable. It can bend and stretch its procedures-imdeed, it must do $\mathrm{so}^{89}$-and at the reinedial stage there is less danger of doing violence to the judicial process by inoving flexibly "beyond the traditional judicial role." At that point, "in actively shaping and monitoring the decree, mediating between the parties, developing his own sources of expertise and inforination, the trial judge has passed beyond even the role of legislator and has beconie a policy planner and manager." 91

There are times when lore inakes law. What $I$ have described is the emerging lore of hitigation for organizational change: it nuust be done; it can be done; it can be done principally by overcoming obstacles set up by the defendants and by using unconventional devices; and it can be done with little impact on the judiciary itself. Here is a credo at once rational and skeptical, intolerant of flexibility, discretion, and expertise in the organizations subject to judicial supervision but exceedingly trustful of all three when employed in the service of the court. Indeed, central to what is fast becoming the received wisdom is the need for expertise in shaping and enforcing renedies, for judicial discretion in framing and nuonitoring novel remedial devices, and for flexibility in adapting the machinery of the courts to the job. The old virtues have found a new honie.

\section{The Character of the Judicial Task}

The use of litigation to effect change in large, complex, ongoing, public institutions is a more hazardous venture than it is frequently niade out to be. Several aspects of the judicial perspective contribute to the problematic character of the enterprise. So, too, do the nature and behavior of public institutions, both in and outside of litigation. Institutional reform litigation has elenients of a shadow play, and never more so than when the practice of adjudication ineets the behavior of organizations.

87. Coffin, supra note 79 , at 997 .

88. Johnson, supra note 79, at 274; see Coffin, supra note 79, at 986.

89. See Coffin, supra note 79 , at 993.

90. Id. at 985.

91. Chayes, The Role of the Judge in Public Law Litigation, 89 HaRv. L. Rev. 1281, 1302 (1976). 
The point is best made by illustration, beginning with the way courts characterize problems and running through a variety of assumptions they indulge in the course of this litigation.

\section{A. Identifying the Issues.}

Courts speak the language of legal rights. It is the language we expect them to speak, and it is the language that frames their charter to speak at all. Accordingly, in prison reform cases, or mental lospital reform cases, or welfare reform cases, or housing reform cases, courts have declared legal rights and identified the denial of those rights as the basis for action. Of course, every decisionmaker plays a creative role $\mathrm{m}$ identifying and labeling a problem as one kind of problem or another. Decisionmakers are much influenced by their standard repertoire in how they choose to identify a problem. So it is to be expected that courts will label institutional problems as raising issues involving rights.

But suppose, imstead, we label the problem a matter of resources and we conclude that a prison or housing case does not involve a demal of rights but a deficiency of finance. Naturally, the two are not necessarily mutually exclusive, for inadequate resources might produce a demal of rights; but whether the analysis rests on the one or the other makes enormous practical differences. If the problem is a resource problem, it will be nnore difficult to argue that it is a problem for the courts at all. If, despite casting the problem im terms of resources, it is a problem for the courts, then the appropriate defendants are not necessarily the administrative body and its officials but the legislators who appropriate funds. And the issue inay not be how to restore rights that have been denied but how much funding is appropriate, especially in relation to competing needs.

Or, agam, suppose, in a inental hospital, the problein is not identified in terms of rights but in terms of appropriate therapy. The imquiry will be different, the parties might be different, the considerations that go mto a decision will surely be different, and so will the remedy. One can produce various hybrids of these: the "right to treatinent" is the most common formulation. ${ }^{92}$ But it leads miniediately to further questions. What is the appropriate treatment? How does a court choose among contending schools of therapeutic intervention? How does it guard against freezing into law what are really ephemeral doctrimes and dogmas of professions groping toward understanding? And how

92. See Wyatt v. Aderholt, 503 F.2d 1305 (5th Cir. 1974); New York State Ass'n for Retarded Children v. Carey, 393 F. Supp. 715 (E.D.N.Y. 1975). 
far must a court follow a decree embodying some such standards to adjudicate secondary consequences-that is, the consequences of the consequences of the decree?

An exanple of these dilemmas is readily at hand. In $\mathrm{New}$ York State Association of Retarded Children $v$. Carey,, 93 a district court approved a consent decree that required officials operating the Willowbrook facility for the mentally retarded to "ready each resident . . . for life in the community at large." 94 This decree was very nuch a product of the prevailing wisdom that "deinstitutionalization" and "inainstreamimg" (placeinent im the community) of the retarded are generally preferable to their confinement. As a result of the decree, some 1000 Willowbrook residents were relocated in the community. Those of school age were enrolled im the public schools. It then developed that about forty of those school children were carriers of serum hepatitis. After consultation with specialists in that disease, the board of education ordered retarded children who were carriers to be excluded from the public schools. The next day, suit was brought by the state commissioner of the office of mental retardation to enjom the board's action. The new action was consolidated with the mam Willowbrook case. The district court then held that the board acted unlawfully, whereupon the board developed a plan to place the hepatitis carriers in separate classes. This, too, the district court held to be unlawful.95 Affirming, the court of appeals decided that the health hazard posed by the carriers was remote, whereas the harm to them that might result from changing classes and having fewer curriculuin options was potentially significant. ${ }^{96}$

The implication of a right to treatment in the Willowbrook case was acceptance of a particular expert view of how such problems should be handled. Once this was implemented, it later becaine necessary to evaluate various alternatives, the appropriateness of which depended upon assessment of two competing sets of unknowns: medical uncertainties about a disease whose transmission is imperfectly understood, on the one hand, and, on the other, educational imponderables about the likely impact of one or another classroom arrangement on learning-impaired pupils. The court essentially followed the children out of the mstitution and into the schools. As it did, new fields of expertise became relevant to evaluation of second-order consequences.

93. 393 F. Supp. 715 (E.D.N.Y. 1975).

94. New York State Ass'n for Retarded Children v. Carey, 612 F.2d 644, 646 (2d Cir. 1979).

95. New York State Ass'n for Retarded Children v. Carey, 466 F. Supp. 479, 486 (E.D.N.Y. 1978), aff d, 612 F.2d 644 (2d Cir. 1979).

96. New York State Ass'n for Retarded Children v. Carey, 612 F.2d 644, 650 (2d Cir. 1979). 
What began as a case involving a custodial institution had become a case involving schools and public health practice. And the court ended by overruling professional judgment on both counts.

Comparable dilemmas exist in certain school desegregation cases. If the right is to an integrated classroom, then the transportation of pupils to achieve that end is appropriate. Suppose, on the other hand, a court asks why a school has become segregated. It may conclude that residential patterns are responsible. If it does, then its order may deal as much with housing as with the school. ${ }^{97}$ The definition of the issue dictates the direction of the response and the scope of the resultimg reinedy.

In all of these cases, the choice is essentially between defining the issue narrowly, in terms of rights, and defining it broadly, in terms of resources, therapy, policy, or the etiology of a social problem. There is, in many cases, no real exit from this dilemma. Casting the issue narrowly risks a significant degree of unrealism in the diagnosis of the underlymg problem and the prescription formulated for it, although it preserves the fiction that this is a lawsuit like any other. Casting the issue broadly risks judicial involvement in a host of issues far from those initially before the court and far from those with which most courts feel comfortable. Courts have gone both ways, and both courses tend eventually to bring home in different ways the lesson that these cases are not principally about legal riglts but about a great many other things: resources, costs and benefits, competing social goals, and professional judginent, to name a few. ${ }^{98}$

\section{B. Identifying the Parties.}

Here there are five assumptions typically indulged by the courtsand often incorrectly: first, that the plaintiffs have discermible, hoinogeneous interests; second, that the defendants are officials of organizations with an identifiable and coherent structure; third, that the relevant organizations are before the court; fourth, that the defendant organizations have more or less consistent interests; and, fifth, that plaintiffs and defendants are on opposite sides of the case.

1. Heterogeneity Among Plaintifs. It has been remarked fairly frequently that plaintiffs often have interests and preferences that di-

97. See Hart v. Community School Bd., 383 F. Supp. 699, 752-54 (E.D.N.Y. 1974), further proceedings at 383 F. Supp. 769 (E.D.N.Y. 1974), affd, 512 F.2d 37 (2d Cir. 1975).

98. See generally Glazer, Should Judges Administer Social Services?, 50 PUB. INTEREST 64 (1978). 
verge one from another. ${ }^{99}$ This observation is entirely accurate. Moreover, the divergence of imterest often shapes the course of the litigation. In a desegregation case, ${ }^{100}$ for example, two classes of plaintiffs differed in their view of housing issues. Minority plaintiffs wanted first priority for local residents in new housing, while white plaintiffs wanted to use the new units to attract higher mcoine people from outside the area. ${ }^{101}$ Largely because of their inability to compose such differences, the plaintiffs focused not on housing, but on the composition of the school.

2. The Coherence of Government Bodies. On the defendants' side, the matter is far more subtle, because it involves characteristic patterns of administrative agency behavior that have been uncovered by students of organization theory and bureaucratic politics. Although our law tends to assume that an administrative agency is a coherent organization, more or less centrally directed and therefore amenable to a change of direction, in poimt of fact such organizations are often far from coherent and far from centrally directed. They are sustamed by relations with various external constituencies (legislators, executives, various chent groups) and typically are composed of a variety of factions and interests internally. Often imternal factions are linked to particular external interests. As these linkages and divisions may outlast even protracted litigation, they are formidable constraints with which courts must contend. What looks like a solidary body may turn out to be a constellation of bodies over which central control is elusive. The implications of organizational fragmentation are discussed below.

3. The Completeness of the Parties. Quite apart from the heterogeneity of seemingly homogeneous organizations, it can by no means be assumed that all the relevant bodies are before the court. Consider the Boston school system, long the subject of desegregation litigation. ${ }^{102}$ The charter of the school system empowered the school committee to appropriate the same funds im any fiscal year as had been appropriated the year before. But, if additional funds were sought, the concurrence of non-parties, the mayor and city council, was required. New appropriations required by court order set in motion a joint budgetimg process, and the expenditure of funds had to be jomtly certified

99. See, e.g., Wilton, Functional Interest Advocacy in Modern Complex Litigation, 60 WASH. U.L.Q. 37 (1982).

100. See Hart v. Community School Bd., 512 F.2d 37 (2d Cir. 1975).

101. Berger, Away from the Court House and into the Field: The Odyssey of a Special Master, 78 COLUM. L. Rev. 707, 726 n.21 (1978).

102. Morgan v. McDonough, 540 F.2d 527 (1st Cir. 1976), cert. denied, 429 U.S. 1042 (1977). 
by the city auditor and the school system business manager. ${ }^{103}$ To be subject to a decree and to have formal authority to carry it out are not necessarily the same as being able to carry it out alone.

Indeed, because legal concepts of responsibility are predominantly formal, whereas organizational behavior is so heavily affected by an array of informal relationships, unpredictability stalks the manner in which a decree will be implemented. In Hobson v. Hansen, ${ }^{104}$ for example, a federal district judge ordered the equalization of expenditures per pupil on teachers' salaries and benefits from school to school within a single school system. The court envisioned that older and more highly paid classroom teachers would then be nore equally distributed through the system. What happened was quite different. For some years after the decree was entered, the systein was able to comply without transferring classroom teachers. Instead, it shifted around itinerant and lower-semority special-subject teachers (those teaching peripheral or enrichment subjects). In choosing this mode of ineeting the requirements of the decree, the systein was much influenced by its obligations under a collective bargaming agreeinent. The teachers' union, which was not a party to the suit-and legally did not have to be-played a powerful and wholly unconteinplated role in the way the decree was effectuated. 105

This important point needs to be put more generally. Even in a complex lawsuit with many parties, it is quite likely that soine major actors in the field have been left out of the litigation. By labeling a controversy a legal question, the judicial process simplifies the issues and the parties. Parties excluded froin participation in the hitigation by this definition of the issue are likely to appear agam later, at the implementation stage, at which point their participation may thwart, deflect, or otherwise impinge upon the implementation of the decree, often producing unintended consequences and preventing the attainment of imtended consequences.

4. Heterogeneity Among Defendants. To the extent that there is more than one defendant-organization before the court-and there usually is-it caimot be assumed that the defendants all have the same view of the litigation or of any issue in it. Quite the contrary. Govern-

103. Wood, Professionals at Bay: Managing Boston's Public Schools, 1 J. Pol'y ANALYsis \& MGMT. 454, 463 (1982).

104. 327 F. Supp. 844 (D.D.C. 1971).

105. D. Horowitz, The Courts ANd Social Policy 146-49 (1977). 
mental bodies will typically respond according to their varying interests, and their responses may change over time. ${ }^{106}$

The difficulties this can cause are well illustrated by Mills $v$. Board of Education, ${ }^{107}$ a "right to education" case in which a federal district court ordered city and school officials to provide education for pupils previously excluded froin the schools because they were disorderly, disturbed, retarded, or hyperactive. Two government bodies were principally affected: the city Department of Human Resources, responsible for children who were wards of the court, and the school system, responsible for pupils who could be placed in nonresidential school programs. Neither agency, however, was willing to take responsibility for children who were not wards of the court but needed residential care. The result was a stalemate that activated a dormant bureaucratic dispute, delayed implementation of the decree, and placed the judge in the role of mediator between warring organizations. ${ }^{108}$

\section{Friendly Persuasion: The Problem of Defendants Who Would} Like to Lose. There is an excellent possibility that some of the governmental defendants agree with the arguments advanced by the plaimtiffs-or, more properly, since these are often lawyer-controlled cases with merely nominal plaintiffs, agree with the arguments advanced by the plaintiffs' lawyers and their expert witnesses. Among lawyers and experts, there may well be elements of a professional consensus at work on both sides. There is commonly also a desire on the part of some officials to use a decree entered against them as a weapon in the political struggle to vindicate their view of the appropriate treatment, rehabilitation, or other policy goal for the imstitution. An adverse decree that would require additional spending is also a weapon used by officials to augment their budget. Occasionally, the anticipated budgetary increases are thwarted, ${ }^{109}$ but very often they are not. Whether the defendants' friendly view of the suit derives from policy preferences or budgetary aspirations, the decree becomes a sliortcut around political constraints. ${ }^{110}$

This is one reason wlyy so many consent decrees are entered in imstitutional reforn cases. Nominal defendants are sometimes happy

106. For an example, see M. Rebell \& A. Block, Educational Policy Making and the COURTS 75-122 (1982).

107. 348 F. Supp. 866 (D.D.C. 1972).

108. D. Horowitz, The Courts and Social Policy 272 (1977).

109. Id. at 258-59.

110. Cf. Diver, The Judge as Political Powerbroker: Superintending Structural Change in Public Institutions, 65 VA. L. REv. 43, 87 (1979). 
to be sued and happier still to lose. ${ }^{111}$ There is an added burden on the courts if they perceive the defendants' posture accurately and if they move beyond what is likely to be their initial reaction - that if even the defendants are agreeable to the remedy requested by the plaintiffs that must be the remedy the angels themselves would decree. In addition to the usual problems attendant upon this hitigation, difficult enough in themselves, there are, then, the problems that arise from the use of the lawsuit by officials seeking to escape political accountability. ${ }^{112}$ The more such strategies succeed, the inore frequently they will be einployed. For, if litigation results in augmented expenditures for the losmg agency, then programs not in litigation will suffer as a result of their mability to bring pohtical pressure to bear on the legislature.

\section{Identifying the Goals of Judicial Intervention.}

The traditional model of the lawsuit is that it is an event with a beginning, a middle, and an end. The beginning comprises the statement of the clain and the raising of issues; the iniddle entails the resolution of the legal and factual issues; the end is defined by the issuance of an order and comphance with it. Since I am concerned here with the matter of judicial supervision of administration, it is the end of the litigation that I should like to highlight. Accurate as it is to describe a great deal of conventional litigation, at no point is the traditional model more out of joint with organizational behavior than at the postdecree stage.

The assumptions carried by the traditional inodel into institutional reform litigation are easily stated. A decree, when rendered, demands compliance. If the requirements of a decree are not fulfilled, there must be noncompliance, typically because of "bureaucratic intransigence." To achieve comphance, some combmation of coercion (or threat of coercion), persistence, and expertise-the latter two often embodied in the person of a special master-is necessary. Once bureaucratic obstacles are overcome, the goals of the decree should be achieved, and the requisite change intplemented.

On every count, organization theory and experience are contrary

111. In a book I wrote on government lawyers, I entitled a section on a comparable phenomenon, "Better to Have Litigated and Lost Than Never to Have Litigated At All." D. Horowirz, The Jurocracy: Government LaWyers, Agency Programs, and Judicial Decisions 84-90 (1977).

112. Against such efforts, the federal courts evolved rules to offset the possibility that, "by means of a friendly suit, a party beaten in the legislature could transfer to the courts an inquiry as to the constitutionahity of the legislative act." Chicago \& Grand Trunk Ry. v. Wellman, 143 U.S. 339, 345 (1892). Compare Rhodes v. Chapınan, 452 U.S. 337, 360 (1981)(Brennan, J., concurring). 
to these assumptions. ${ }^{113}$ No doubt compliance was a major problem in the early desegregation cases, but it is not the major problem any more. As previously indicated, many of the defendants are at least sympathetic to the objectives of the decree. Whether they are or not, what typically happens after a decree is rendered is that a host of forces and imterests, only some of them represented in the litigation, comes into play. Depending on the character of the affected institution, these may be parents, unions, professional organizations, interest groups, or political leaders in the executive or legislature. As I have notcd, an administrative agency is only nominally a single organization. In fact, it is dependent on many others in the environment in which it functions to fulfill its mission. In the scliool equalization case, discussed above, the preexisting contract between the scliool systen 1 and the teachers' union liad a pronounced impact on the way the system complied with the decree, although neither the union nor the terms of the contract had been before the court. In the Boston scliool desegregation case, the court's effort to involve the cominunity in the selection of scliool administrators in order to "break up the 'old boy' network . . . was easily subverted in practice through the process of bullet voting by the separate constituencies." 114 The decree was complied with, but the goal was unfulfilled. Not compliance or noncompliance, but mode of compliance, determines the impact of a decree. And mode of compliance is dependent on the interplay of actors whose behavior is usually beyond the anticipation and often beyond the reach of the court issuing the decree.

Accordingly, the problen is not low to coerce the organization into compliance. Like others who issue complex orders, the actions of courts inevitably must "reflect the realities of partial enforcentent."115 Courts have, of course, discovered this, as they liave detected the nced to readjust their decrees at later stages to cope with unforeseen conditions. But it has not been an easy lesson. Many courts still speak of the need to cut througl bureaucracy to achieve goals stated in absolute terms. Often the only way to reconcile the world of inultiple organizational constraimts with the desire for full enforcement has been to cliop up the legal requirenients imposed into small, measurable pieces-im a

113. For a general view from the perspective of "enforcement," see Diver, $A$ Theory of Regula. tory Enforcement, 28 PUB. Pol'y 257 (1980). See also A. Etzion, A Comparative ANALYsis of Complex Organizations (rev. ed. 1975); H. Kaufman, The limits of Organizational Change (1971); H. Simon, Administrative Behavior (3d ed. 1976); Note, Judicial Intervention and Organization Theory: Changing Bureaucratic Behavior and Policy, 89 YALE L.J. 513 (1980).

114. Wood, Professionals at Bay: Managing Boston's Public Schools, 1 J. POL'Y ANALYsIs \& MGMT. 454, 462 (1982).

115. Diver, A Theory of Regulatory Enforcement, 28 PUB. PoL'y 257, 259 (1980). 
prison, for example, so many square feet of living space, so many inmates to each physician, and so on.

Then, too, the notion that a lawsuit is a finite piece of business, with a clearly-defined end, has not been easy to reconcile with the exigencies of organizational change litigation. Only slowly and reluctantly have courts, accustomed to a varied diet of lawsuits that actually terminate, become adjusted to the idea that organizational change is not a finite matter, that institutional reform cases do not seem to liave a clear end-poimt. There has been much impatience and occasionally intemperance along the way to this realization, and many of the issues raised by the use of special masters, discussed below, revolve around the desire of the court finally to work its will on the organization. The diffuse, fluid character of organizational behavior has proved a very frustratimg matter to courts accustomed to ascertaining "the facts," deciding the case, and counting on "compliance." A principal result of a fair number of decrees has been, not compliance or its absence, but further proceedings. ${ }^{116}$ Many cases have proved to be, like the Willowbrook litigation, chameleon cases, ever-new, ever-changing, neverending.

Interestingly enough, the complaint of administrators is not that there are too many subsequent proceedings, including modifications of the origmal decree, but rather too few: they complain that they are bound by orders with which they cannot comply, because the litigation setting is not fluid enough to cope with a changing environment. ${ }^{117}$ The perspectives of the courts and of the organizations they seek to change are, $m$ the nature of things, radically different.

\section{Masters, Machinery, and the Willingness to Innovate.}

The complexity and time-consuming character of judicial supervision of administrative bodies have led courts to innovate in enforcement mechamisms. Among the more common devices is appointment of a special master, a momitor, a review committee, or, in more extreme cases, a receiver to take over administration of the agency. I have recounted above how the contours of Rule 53 have been reshaped to permit employment of masters, even after entry of the decree and for tasks other than fact-finding. But what have such adjunct officials done, and what is their significance for this hitigation and for the courts that appointed them?

116. See, e.g., M. Rebell \& A. Block, Educational Policymaking and the Courts 122 (1982).

117. Wood, Professionals at Bay: Managing Boston's Public Schools, 1 J. Pol'y ANALYsis \& MGMT. 454, 462 (1982). 
Masters have been appointed for a variety of purposes at several stages of the litigation: to propose the terms of a decree, either initially or after earlier proposals had been rejected; to cope with anticipated resistance to the decree; to supervise compliance with the decree; to negotiate with actors whose cooperation would be necessary to secure implementation; to advise and assist the defendant organization; to monitor the conduct of the organization and provide intelligence to the judge about its behavior; to be alert to the need to annend the decree; and to resolve disputes over the ineaning of the decree. ${ }^{118}$

Sometimes the terms of appointnient liave been exceedingly broad. In a Rhode Island prison case, a master was einpowered to momitor compliance with the decree. ${ }^{119}$ For this purpose, he was accorded unlimited access to the facilities at any hour; he was permitted to conduct confidential interviews with prison staff and prisoners, to attend staff meetings, and to recommend transfer of staff members and the hiring of new einployees. Other masters liave essentially provided themselves a broad charter. In the Coney Island school case, ${ }^{120}$ the special master employed to propose a remedial plan proceeded to conduct no hearimgs. Instead, he hired a research assistant, met with community groups and the mayor, sat at the feet of a Ford Foundation program officer working in the field of his concern, and cooperated extensively with the defendants in framing his recommendation. ${ }^{121}$ Acknowledging that this cooperation "ignored . . . the quasi-adversarial relationship between the court . . . and the various agencies,"122 he concluded that the investigation and negotiation in which he engaged were nonetheless necessary to the "legislative" task of shaping "systeinic change."123 In short, 1nasters are appointed to make good the deficiencies of the judicial process in coping with complex organizations.

There is the rub. Precisely because masters sense the need to act unconventionally, they test the boundaries of judicial propriety. They soinetimes engage in what would clearly be improper ex parte commu-

118. Kirp \& Babcock, Judge and Company: Court-Appointed Masters, School Desegregation, and Institutional Reform, 32 ALA. L. REv. 313 (1981); Nathan, The Use of Masters in Institutional Reform Litigation, 10 U. ToL. L. REv. 419 (1979).

119. See Palmigiano v. Garrahy, 443 F. Supp. 956, 989 (D.R.I. 1977), aff d, 616 F.2d 598 (1st Cir.), cert. denied, 449 U.S. 839 (1980).

120. Hart v. Community School Bd., 383 F. Supp. 699 (E.D.N.Y. 1974), supplemented, 383 F. Supp. 769 (1974), aff d, 512 F.2d 37 (2d Cir. 1975).

121. Berger, Away From The Court House and into the Field: The Odyssey of a Special Master, 78 COLum. L. Rev. 707 (1978).

122. Id. at 723 .

123. Id. at 738 . 
mications if engaged in by the judge. If they rely more heavily on one side or the other for information or for cooperation in drafting a plan, they risk the appearance or the reahty of lost neutrahty. If they hire subordinate personnel, they delegate some part of their function, thus removing the judge a second step from the action taken. If they use their power to interview staff meinbers, to recommend staff changes, or to give orders to staff on operational matters, they may intrude unduly into administration and raise questions of organizational accountability. and lines of authority. ${ }^{124}$ If, in inonitoring a decree, they commit theinselves to a certain view of who is responsible for shortfalls in implementation, they risk partisan commitment, in which they inay also entangle the judge if he accepts their view of the matter, even after a formal hearimg.

Perhaps unsurprisingly, then, it turns out that appointing courts occasionally disown what the master has done or proposed. ${ }^{125}$ The unconventional character of the initial appointment leads to unconventional behavior, for organizational change cases are different from the normal run of cases. What masters propose sometimes appears too ainbitious or too risky or too politically entangling to the judges who àppointed them.

Appellate courts have also been soinewhat cautious in reviewing the employment of masters. In the Willowbrook case, for instance, a district court held the governor and state controller in contempt for failing to fund a seven-member "review panel" einpowered to oversee implementation of a consent decree. The state officials had requested funding, but the legislature did not coinply. The Court of Appeals for the Second Circuit reversed the conteinpt finding, holding that the governor was not obliged to expend nnappropriated funds. ${ }^{126}$ In a significant footnote, the court added that it did not necessarily "agree with the view that a federal court properly exercises its function when it takes upon itself the supervision of a state institution like Willowbrook Development Center," for that is a time-consuming responsibility. ${ }^{127}$ Similarly, in an Alabama prison case, the Fifth Circuit declined to approve a thirty-nine member "Human Rights Committee," plus consultants and clerical staff, appointed by the district court to monitor

124. Cf. Wood, Professionals at Bay: Managing Boston's Public Schools, 1 J. PoL'y ANalysis \& MGMT. 454, 462 (1982) ("Court experts gave oral instructions to key officers in the school departunent, who understandably were uncertain as to whether they worked for the experts, the court, or the superintendent.").

125. Kirp \& Babcock, Judge and Company: Court-Appointed Masters, School Desegregation, and Institutional Reform, 32 ALA. L. Rev. 313, 370 (1981).

126. New York State Ass'n for Retarded Children v. Carey, 631 F.2d 162 (2d Cir. 1980).

127. Id. at 166 n.3. 
implementation of its decree. ${ }^{128}$ The court of appeals was apparently concerned about two things. First, it was troubled by the size and therefore likely intrusiveness of the body. Second, the court sensed that the breadth of the committee's mandate ("to take any action reasonably necessary") was conducive to the committee's taking over administration of the prison, which, the court noted, "appears to have occurred." 129 The court of appeals noted in passing the assertion of state officials that "prison authorities and their counsel were not notified of meetings between committee members and the District Court with reference to prison operations; therefore, state counsel were unable to participate or to be heard." 130

Masters are still readily appointed and approved. Where skepticism has surfaced, its source has been the desire to avoid intrusiveness in administration and to supersede administrative officials only as a last resort. The appellate courts have been concerned with the potential for deep and unending involvement of district courts in the affairs of public imstitutions. Although the oblique reference to ex parte communications in the Alabama case suggests soine uneasiness, the courts have been much less concerned with the feedback impact of masters, monitors, and receivers on the courts and on the integrity of judicial proceedings.

Quite the contrary, in fact. The courts have been insufficiently diligent about protecting themselves in this respect. Two cogent examples can be cited, one a recent case, the other a recent set of proposals.

In a case arising in the Massacliusetts courts, the Supreme Judicial Court approved the appointment of a receiver to take over administration of the Boston Housing Authority.131 At the same time, the court reviewed certain ex parte conversations the trial judge had had with the receiver. Such conversations, the court noted, should not have occurred. But, on the other liand, said the court, it is only "natural" that they did occur: this, after all, was "massive, long-contmuing litigation which has approximated the type imvolving imstitutional reform." 132 Citmg acadeinic commentators who have described the role of the judge as manager, the opinion goes on to explam: "Necessarily the judge becomes interested in operational problems and it is understandable that he slould begin to act the part of an operator with perhaps

128. Newman v. Alabama, 559 F.2d 283, 288-90 (5th Cir. 1977), cert. denied, 438 U.S. 915 (1978).

129. 559 F.2d at 289.

130. Id. (emphasis deleted).

131. Perez v. Boston Hous. Auth., 379 Mass. 703, 400 N.E.2d 1231 (1980).

132. Id. at 741,400 N.E.2d at 1253. 
reduced attention to such conventional safeguards as bilaterahty."133 "Bilaterality," it should be understood, is a euphemism for confrontation and cross-examination and other procedures to avoid ex parte cominunications. In the same tolerant spirit, the court turned aside objections to the trial judge's vehement criticism of the Boston Housing Authority $m$ the later stages of the litigation. This veliemence was produced, according to the appellate court, "by the judge's frustration at what he took to be the poor reaction of the BHA people to his orders and directions and latterly to the requirements of the consent decree ...."."134

What the Boston housing case illustrates, in addition to the obvious dangers of ex parte cominunications and of delegation of judicial functions to masters and receivers, is the tendency noted earlier for courts to assuine that, if a decree is not fully effective, bureaucratic resistance must be the reason. As the court beconnes committed to attaining the result posited by the decree, there is a substantial risk that the court will become a partisan in a struggle to bring the bureaucracy to heel. All of these are formidable dangers posed by imstitutional reform litigation for the integrity of the judicial process. Extraordmary cases seem to denand extraordmary ineasures, but extraordinary measures may, in the end, contaminate the handling of ordinary cases. Presumably, there are sharp limits to the extent the functioning of courts will be unaffected by ex parte cominunications and by judges who act as partisan "operators" in the enforcement of their decrees.

The proposals are those inade by Judge Frank M. Coffin, who has suggested major procedural changes to accominodate the exigencies of organizational change litigation. ${ }^{135} \mathrm{He}$ is prepared to permit an "outside expert judge" to sit in on the remedial phase, since ex parte "influence would not seem to be of as much concern at the remedial stage as when liability is at issue."136 Judge Coffin also recominends that appellate judges "sit im on critical argunents [im the trial court], absorb the atmosphere, gam a better appreciation of the problem, and help inform the court of appeals so that it could play a more sensitive role."137 Likewise, Judge Coffin would sanction conferences between trial and appellate judges before the trial judge decides on a remedy, ${ }^{138}$ and he advocates the participation of the trial judge as "a resource per-

133. Id. at 742,400 N.E.2d at 1254 .

134. Id. at $740-41,400$ N.E.2d at 1253 .

135. Coffin, The Frontier of Remedies: A Call for Exploration, 67 CALIF. L. REv. 983 (1979).

136. Id. at 996.

137. Id.

138. Id. at 990. 
son" at the appellate argument. ${ }^{139} \mathrm{He}$ is ready to adapt existing institutions in drainatic ways to make possible inquisitorial procedures by trial judges and to make available to thein "the help of proven experts." 140 Frustration with the inadequacy of the courts to cope with organizational change hitigation has thus generated a willingness to tinker with procedure in quite fundamental ways, with very little awareness that such changes might redound to the disadvantage of the systein as a whole.

The earlier apprehensions about the hiberal employment of special masters are not entirely dissipated, but they have been much diluted. In the enthusiasm to inanage organizational change, courts, although fearful of becoming too involved in administrative matters, have largely forgotten the dangers to the integrity of the judicial function that inhere in ex parte communications, in delegation of the duty to decide from judges to their nominees, and in even temporary abandonment of the appearance of judicial neutrahity. The courts have begun to assume that, to do the job effectively, they require more in the way of machinery-nore "experts," more masters and monitors, more consultantsand this in a judicial system that has thrived on an absence of machinery. Courts may or may not succeed in reforming bureaucracies, but in the course of trying they nay end up transforming themselves. In the United States, it has always been clear that what a court has decided, a judge has personally decided. In the end, too much machinery between the court and the case puts at risk a distinctive feature of the American judicial system, namely, that hitigants obtain the compulsory attention of judges.

It would be wise, therefore, not to let frustration with organizational change litigation propel too much enthusiasin for procedural imnovation. There is every reason to be sparing about the use of nnasters, receivers, monitors, experts, and consultants, lest the judiciary, im reforming bureaucracies, jom their ranks. The assumption of procedural malleability is quite accurate. Our courts can be what we want them to be and do what we want them to do. But they camiot be and do everything. Even if alterations like those proposed promised enhanced capacity for institutional reform cases-a doubtful proposition, given what I have suggested are the main reasons for the difficulty of these cases-this benefit would likely come at the cost of mipairing the overall credibility and capacity of the system.

139. Id. at 997.

140. Id. 


\section{The Court as Manager: Toward a Fuller Accounting}

Something important has been happening that has not quite been identified in the profuse literature on organizational reform litigation. The trial judge has been celebrated as "the creator and manager of complex forms of ongoing relief," 141 the one in whom responsibility is lodged to "remove the threat posed to our constitutional values by a large-scale organization" 142 or, more pointedly, "to control the bureaucracies of a complex, modern society." 143 Some sucl role conception has combimed with an implicit model of organizational behavior that emphasizes bureaucratic recalcitrance to produce an imclination on the part of judges to work their will against all obstacles. This has produced, in turn, a fundamental alteration in the criteria by which judicial decisions are to be judged and an investinent of courts in the outcome of controversies on a scale not previously experienced in the United States.

In the so-called conventional case, in which the remedy is simple and follows naturally from the riglits of the parties, great care is taken in declaring those riglits. In evaluating sucli a judicial decision, we typically ask whether or not it is right. To be sure, many complexities are concealed in that question. A decision may be right because it is in accordance witl preexisting law. Or it may be right because it squares witl purposes embodied in some underlying legal doctrine. A decision may be right because it responds to some ethical imperative or to the needs of the parties or because it fits the social milieu in whicl it will have an impact. Still, the touchstone of evaluation is riglitness.

Not quite so in organizational change cases. There the decree is complex; it often does not follow naturally from the declared riglit, and perhaps it should not. ${ }^{144}$ The main question is whether the remedy is apt to bring about the intended result, whether the court can husband sufficient resources to compel or catalyze the desired change. In sliort, the focus is not on rightness alone but also on effectiveness. There has been a pronounced shift from moral to managerial criteria of evaluation of judicial decisions.

The courts themselves lave perceived this, which is why they devote so mucli attention to enforcing their decrees and why they have

141. Chayes, The Role of the Judge in Public Law Litigation, 89 Harv. L. Rev. 1281, 1284 (1976).

142. Fiss, The Supreme Court, 1978 Term-Foreword: The Forms of Justice, 93 HARv. L. REv. 1, 17 (1979).

143. Chayes, The Supreme Court, 1981 Term - Foreword: Public Law Litigation and the Burger Court, 96 HARv. L. Rev. 4, 60 (1982).

144. See id. at 5I-52. 
been willing to be flexible and experimental with devices to that end. Because of this altered focus and also simply because of the drawn-out, time-consuming, frustratimg character of the litigation, a good many judges have become invested in the outcome of the litigation. They want the bureaucracy to change, and they are inclined to regard a failure to change as an indication of defiance for which a response is required. And, so, as in the Boston Housing Authority case, we have witnessed trial judges who become vehemently partisan, because they are "interested in operational problems." 145 Simce enforcement is a key process in institutional reform litigation, and the judge plays a inajor role in it, coinpromises in judicial neutrahty must be expected.

Now this might be an acceptable price to pay if it did not entail a significant loss in coinparative advantage. Most close observers would agree, I think, that courts are generally rather good at applied moral reasoning of the sort they are called upon to perform in conventional adjudication. There is no reason to expect, however, that the leastbureaucratized of the branches of government-and the one most accustoined to autornatic, unswerving obedience to orders-will be particularly adept at management tasks. The courts have a comparative advantage when it comes to adjudicating rights; they have none when it comes to enforcing complex remedies.

Moreover, despite the willingness of courts to innovate in handling this litigation, they are still very much courts, bound for the inost part by a process devised for the adjudication of individual disputes and not especially apt for coping with large questions of policy and administration. This is not the place to identify the range of fact-finding and impact-forecasting problems created by the imperfect fit between an old process and a new set of demands placed on it. I lhave analyzed these extensively elsewhere. ${ }^{146}$ But two problematic aspects of organizational change litigation call for special mention, for they are both specific to the supervision of public institutions and inherent in the judicial inode of proceeding. One has to do with the financial ramifications of institutional reform decrees. The other involves the matter of unintended consequences. I have alluded to both earlier. Still, I want to underscore here the capricious character of outconnes on both of these dimensions, for it bears on what we might, in the end, think of the work of the courts in this area.

When a court decrees that a housing authority, welfare agency, prison systein, or mental hospital must change the way in which it has

145. Perez v. Boston Hous. Auth., 379 Mass. 703, 742, 400 N.E.2d 1231, 1254 (1980).

146. D. Horowitz, THE CourTs ANd Social Policy (1977); Horowitz, The Courts as Guardians of the Public Interest, 37 PUB. AD. Rev. 148 (1977). 
been operating, the changes required may necessitate the expenditure of public funds. Since courts liave largely been deaf to the argument that funds are unavailable for compliance with such a decree, one of two things can happen. Either the organization succeeds in extracting new appropriations to meet the demands of the decree, or else it reallocates existing funds for that purpose. If the former, there is what we miglit call a leveling up. If the latter, there is a leveling down: that is, some service or facility not implicated in the decree suffers an offsetting diminution. Whether there is leveling up or leveling down is generally not a function of how important the right declared by the court is or how vital the affected service is. It is a function of political relationships and pressures entirely extrinsic to any such judgment on the merits. Administrators may collude with plaintiffs' lawyers in the hope of budgetary augmentation, but that lope is not always fulfilled. ${ }^{147}$

Even if new funds are appropriated, that impact may have costs elsewhere. Unless the court has succeeded in galvanizing public support for more expenditures overall, more funds appropriated for, say, improved prison conditions may mean fewer funds for health care or welfare assistance or some other need. Indeed, this is likely, unless those prograins, too, have been the subject of an adverse decree. To the extent that courts are de facto participants in the budgetary process, they order their budgetary priorities seriatim. They operate one case at a time. They never need lay prison needs agamst welfare needs, because they work on the premise that they are declaring rights. If a party has a right, it is not bounded by cost. But that is not how a right is likely to be translated into the appropriations process. Budgeting is not absolute; it is the most relative of processes, the polar opposite of rights adjudication. Courts, however, see only the beneficiaries of their decrees, never those who lose resources as a result.

This brings me to the more general subject of unintended consequences in organizational change cases. As im the matter of budgetary costs, these are of two types: those that occur within the affected organization and those that occur outside it. I have already suggested that, after a decree is entered, a plethora of forccs, many of them not before the court, typically combine in unanticipated ways to produce results of which courts may or may not approve but many of which they will certainly not have foreseen. The same happens outside the bounds of

147. See Milliken v. Bradley, 433 U.S. 267, 293-95 (1977) (Powell, J., concurring). In Mills v. Board of Educ., 348 F. Supp. 866 (D.D.C. 1972), the school system had hoped that an adverse decree would augment its budget, but a change of superintendents occurred, and the new administrators proved less adept at persuading city officials of the need for additional funds. 
the affected organization. These consequences never come within the view of the courts.

Prison litigation provides an excellent example. Through the 1970 's, there was a dramatic increase in decrees ordering the amehoration of prison conditions and the reduction of overcrowding. The decrees had a variety of effects, alone and in combination with other forces. The conditions in which some prisoners were loused certainly improved, but authorities sometimes were impelled to comply with judicially-imposed space requirements by shifting some prison inmates into inuch less adequate local jails. ${ }^{148}$ Some prisoners were plainly worse off after the decrees. In at least some state institutions, judicial recognition of prisoners' rights seems also to have loosened the authority and self-confidence of custodial persormel and concomitantly strengthencd the power of prison gangs, making inmates more vulnerable to physical abuse. ${ }^{149}$ One prisoner's right may be another's torment. As far as I know, no court has thought of prison rcform litigation in terms of offsetting costs and benefits.

Prison hitigation and mandatory sentencing together produced an unanticipated legislative response. By the end of the 1970's, individual prisons or whole prison systems in some thirty-seven states were subject to court order or pending litigation. ${ }^{150}$ The same decade witnessed the enactment of mandatory sentencing statutes, also in as many as thirtyseven states. ${ }^{151}$ Prison reform decrees combined with determinate sentences to put great pressure on existimg prison facilities and to make construction of new facilities look increasimgly attractive to decisionmakers. The result has been a prison building boom all around the United States. Some 600 new correctional facilities were being constructed in forty-five states as of 1979 , at a cost in excess of $\$ 3.5$ billion. ${ }^{152}$ Courts had helped put corrections on the agenda of legislatures, to be sure, but the response was a prison building program, in part to avert adverse decrees. It hardly needs to be said that this is not at all the way prison reformers wanted the issue to be framed in state legislatures: they were interested in alternatives to incarceration, in fewer prisons, not inore. The courts and the new sentencing statutes

148. National Institute of Justice, Conditions and Costs of Confinement 163 (1980) (volume 3 of the AMERICAN PRISONS AND Jalls series).

149. M. HARRIS \& D. SPILler, AfTer DeCision: IMPLEMENTATION OF Judicial DECREES IN CORRECTIONAL Settings 112-13, 408-09 (1977); Engel \& Rothman, Prison Violence and the Paradox of Reform, 73 PUB. INTEREST 91, 100-01 (1983).

150. See supra note 61.

151. W. BURGER, 1982 YEAR-END REPORT ON THE JUDICIARY 6-7 (1983).

152. See Joy, State Prisons on Trial, 5 State Legislatures 6 (1979). 
effectively preempted that whole issue, locking us into prisons until the twenty-first century.

Now it is perfectly accurate to describe the judicial role in these cases as managerial. But it is wrong to stop at the boundaries of the defendant-organization. The judges, in fact, manage much inore than they know. And it is equally wrong to judge the efficacy of their efforts by whether they have removed the "threat" posed by an organization to "constitutional values" or whether they have "controlled the bureaucracy." For that would be to do exactly what the courts themselves rather unreahistically do in this litigation: isolate pieces of transactions and related institutions, act on a piece, and neglect the rest. Litigation inevitably entails this sort of simplification. At such habits did T.R. Powell aim his remark that "If you can think about something which is attached to something else without thinking about what it is attached to, then you have what is called a legal mind." If this turn of mind is necessary in litigation, it certainly is not helpful in evaluating the effect of litigation.

If we resist the tendency to evaluate organizational change litigation through the narrow-angle lens of compliance alone, soine other matters come prominently into the range of consideration. Among these is the likely impact of unconventional judicial enforcement practices on the courts themselves. Does the growing use of masters, monitors, and receivers threaten the integrity of the judicial process because of the informal, ex parte way in which they operate or because of the new personnel placed between the judge and the case? To what extent should the proliferation of extensive decrees largely shielded from appellate review by doctrimes of remedial discretion or by the insulation of techuncal fact-finding give cause for concern that single district judges can order the reshaping of whole institutions? Do the changing criteria for evaluating judicial decisions, froin moral to inanagerial, put the courts in an untenable position, a position conducive to judicial frustration and the loss of neutrality? When we consider these matters, along with the unpredictable financial results of decrees, the ability of parties not before the court to skew the implementation of decrees in uncontemplated ways, and the unintended impact of judicial intervention in other forums (such as legislatures) - when a inore accurate accounting of this kind is attempted, the enrerging picture is simply not in focus. Whether the courts have done more good than harm is a question begging an answer at the moment. That they inean to do good is beyond doubt. But, as Peter de Vries has observed, "The road to good intentions is paved with hell." 